\title{
PERANAN PENDIDIKAN KEWARGANEGARAAN TERHADAP PEMBANGUNAN KARAKTER BANGSA
}

\author{
HARIYANTO \\ SMPN 202 Jakarta \\ E-mail : hariyanto116825@yahoo.com
}

\begin{abstract}
ABSTRAK
Krisis karakter pada bangsa Indonesia, mengancam nilai karakter bangsa yang bermartabat bagi bangsa Indonesia. Indonesia membutuhkan penanganan untuk menyelesaikan permasalahan karakter bangsa Indonesia yang telah mengalami penurunan terutama di era globalisasi ini. Pendidikan Kewarganegaraan (PKn) merupakan salah satu mata pelajaran yang dalam tujuannya yaitu membentuk karakter bangsa. PKn diwajibkan untuk dipelajari dimulai dari tingkat dasar, menengah sampai dengan pergururan tinggi. Hal ini bertujuan untuk membentuk karakter bangsa Indonesia. Nilai-nilai Pancasila dibentuk berdasarkan budaya yang dimiliki bangsa Indonesia dengan begitu, karakter yang seharusnya melekat pada setiap bangsa Indonesia yaitu karakter yang berlandaskan nilai-nilai Pancasila dalam kehidupan sehari-harinya. Itulah mengapa PKn dipelajari dan diterapkan kepada peserta didik sejak sekolah dasar. Walaupun demikian, pendidikan karakter pada peserta didik tidak akan berhasil apabila hanya bergantung pada lembaga pendidikan saja, perlu adanya kontribusi dari lingkungan sekitarnya pula. Maka dari itu, tidak adil apabila ketidak berhasilan dalam membentuk karakter bangsa justru disalahkan hanya pada satu pihak saja.
\end{abstract}

Kata Kunci : Karakter bangsa, pendidikan, Pendidikan Kewarganegaraan, PKn

\section{PENDAHULUAN}

Karakter bangsa Indonesia mengalami penurunan, ditandai dengan rendahnya etika dan moralitas pada generasi muda Indonesia. Bangsa Indonesia seakan-akan kehilangan jati dirinya, banyak generasi muda yang lebih mencintai budaya luar daripada budaya dalam negeri dan menganggap perilaku negatif bangsa Barat merupakan sesuatu yang keren, seperti sering terjadinya tawuran antar pelajar, tindakan kekerasam ataupun melakukan bullying. Seiring dengan perkembangan teknologi yang semakin mempermudah seseorang pengguna teknologi, salah satunya smartphone untuk mengakses sesuatu yang dapat memberikan dampak positif maupun negatif. Kurangnya kesadaran bangsa terhadap dampak perkembangan teknologi menyebabkan terjadinya penyalah gunaan terhadap teknoogi tersebut. Seperti contoh kasus yang dilansir dari detik News (2018), video viral lima orang siswa SMK NU 03 Kaliwungu, Kabupaten Kendal pada mulanya siswa bercanda dan beberapa saling melempar kertas, hingga kertas terlempar kearah gurunya (Pak Joko), lalu ketika ditanya siapa siswa yang melempar kertas tersebut, tidak ada yang menjawabnya, hingga lima orang siswa maju seakan tidak terjadi apa-apa dan mulai menyentuh tubuh gurunya tersebut. Dari kejadian tersebut, walaupun kepala sekolah mengatakan bahwa kejadian tersebut merupakan candaan, tetap saja tindakan tersebut mencerminkan ketidaksantunan sikap dan perilaku siswa terhadap gurunya.

Dari contoh kasus tersebut sudah mencerminkan rendahnya etika dan moralitas bangsa Indonesia, tindakan yang bertitel candaan sudah jauh dari sikap dan karakter bangsa Indonesia. Viralnya video tersebut, apabila tidak ada tindakan yang lebih serius akan menyebabkan pola pikir bangsa yang mengaggap tindakan tercela tersebut merupakan hal yang biasa dilakukan, sehingga akan ada kemungkinan kejadian tersebut terulang kembali dan karakter bangsa Indonesia semakin rusak.

Tidak hanya generasi muda, kalangan elit politik saja yang seharusnya menjadi teladan bagi generasi muda, sikap dan perilakunya belum pantas untuk ditiru. Contohnya sering kita lihat di televisi, wakil rakyat yang telah melakukan korupsi sering kali masih terlihat tersenyum dan melambaikan tangan, tingkahnya seperti melakukan hal yang biasa saja, hal seperti ini 
merupakan sebagian contoh saja yang sering kita lihat. Tindakan ini bahkan bukan merupakan teladan yang baik untuk diberikan kepada generasi muda.

Berdasarkan keadaan karakter bangsa Indonesia yang sedang krisis ini, diharapkan dengan adanya mata pelajaran/mata kuliah PKn, karakter bangsa Indonesia dapat dibentuk melalui proses pendidikan menjadi warga negara yang baik dan bermartabat. Seperti salah satu misi dari PKn yaitu, sebagai pendidikan karakter, disamping misi lainnya yaitu sebagai pendidikan politik/pendidikan demokrasi, pendidikan moral dan pendidikan hukum pada setiap jenjang dan jenis pendidikan (Susiantik, 2013).

\section{METODE PENELITIAN}

Penelitian ini menggunakan pendekatan studi literatur yang bersumber dari jurnal, buku dan sumber lainnya yang memiliki keterkaitan dengan peranan PKn dan pembentukan karakter bangsa. Sebagaimana menurut Muhadjir (2000) penelitian menggunakan studi literatur atau studi pustaka mencakup: pertama, telaah teoritik suatu disiplin ilmu yang perlu dilanjutkan secara empirik (pengalaman) untuk memperoleh kebenaran. Kedua, studi yang berupaya mempelajari seluruh obyek penelitian secara filosofis atau teoritik dan berkaitan dengan validitas. Ketiga, studi yang berupaya mempelajari teoritik linguistic. Keempat, adalah studi karya sastra. Tujuan dalam menggunakan metode ini adalah untuk memahami dan menemukan validitas mengenai Pendidikan Kewarganegaraan yang mempengaruhi pembentukan karakter bangsa.

\section{PEMBAHASAN}

\section{a. Pentingnya Membangun Karakter Bangsa}

Banyaknya kasus baik di media ataupun sering kita alami yang mencerminkan rusaknya karakter bangsa merupakan suatu pembuktian bahwa pendidikan karakter di Indonesia belum sepenuhnya berhasil diterapkan dalam kehidupan sehari-hari, baik sebagai individu maupun sebagai warga negara. Ini membuktikan bahwa betapa pentingnya pembangunan karekter bangsa Indonesia.

Menurut Undang-Undang RI, No. 20 Tahun 2003 tentang Sistem Pendidikan Nasional menyatakan bahwa pendidikan Nasional berfungsi mengembangkan kemampuan dan membentuk watak serta peradaban bangsa yang bermartabat dalam rangka mebcerdaskan kehidupan bangsa, bertujuan untuk berkembangnya potensi peserta didik agar menjadi manusia yang beriman dan bertakwa kepada Tuhan Yang Maha Esa, berakhlak mulia dan menjadi warga negara yang demokratis serra bertaggung jawab.

Menurut Sulistryarini (2015), dalam lagu Indonesia Raya karya W.R. Supratman berbunyi '...Bangunlah jiwanya, bangunlah badannya untuk Indonesia Raya' pesan tersebut disampaikan mengenai pentingnya membangun karakter bagi bangsa. Dalam lirik lagu tersebut dituliskan membangun 'jiwa' sebagai lirik yang lebih dulu sebelum membangun 'badan', artinya bahwa membangun jiwa yang sehat dan baik lebih diutamakan sebelum membangun badan. Bukan berarti membangun badan tidak penting, hanya saja kita mamperlukan jiwa atau karakter yang baik dan kita membutuhkan badan yang sehat untuk merealisasikan atau mencerminkan karakter yang baik.

Menurut Maswardi Rauf (2008: 88) karakter bangsa terlihat dari pola pikir dan tingkah laku yang selanjutnya menjadi sifat yang melekat bagi bangsa, pedoman warga negara dalam bertingkah laku yaitu budaya atau nilai yang dianut oleh masyarakat itu sendiri. Pendapat tersebut sejalan dengan ideologi Pancasila yang terbentuk dari budaya serta lingkungan masyarakat yang menjadi sebuah pandangan hidup. Dengan begitu, pembinaan nilai-nilai Pancasila harus selalu berjalan, terus dikembangkan, dan dilestarikan karena karakter bangsa Indonesia berlandaskan nilai-nilai Pancasila sebagai pandangan hidupmya. 
Menurut Desain Induk Pembangunan Karakter Bangsa (2010: 7), karakter bangsa merupakan kualitas perilaku kolektif kebangsaan yang unik-baik tercermin dalam kesadaran, pemahaman, rasa, karsa, dan perilaku berbangsa dan bernegara dari hasil olah pikir, olah hati, olah rasa dan karsa, serta olah raga seseorang atau sekelompok orang. Maka dari itu, individu yang memiliki jiwa Pancasila, memiliki nilai-nilai karakter berdasarkan sumbernya sebagai berikut:

1. Olah hati, antara lain beriman dan bertakwa, jujur, amanah, adil, tertib, taat peraturan, bertanggung jawab, berempati, berani mengambil resiko, pantang menyerah, rela berkorban, dan berjiwa patriotic

2. Olah pikiran diantaranya seperti cerdas, kritis, kreatif, inovatif, ingin tahu, produktif (mampu menhasilkan sesuatu), berorientasi iptek dan reflektif

3. Olah raga diantaranya seperti bersih, sehat, sportif, tangguh, andal, berdaya tahan, bersahabat, kooperatif (mampu bekerja sama), kompetitif, ceria dan gigih

4. Olah rasa dan karsa diantaranya kemanusiaan, bergotong royong, kebersamaan, saling menghormati, bertoleransi, berjiwa nasionalis, peduli, kosmopolit (mendunia), mengutamakan kepentingan umum, cinta tanah air, bangga menggunakan bahasa dan produk Indonesia, dinamis, kerja keras, dan beretos kerja (Desain Indik Pembangunan Karakter Bangsa, 2010: 22)

Dengan begitu, karakter bangsa memiliki ciri-ciri berkepribadian yang cenderung tetap, memiliki pola hidup dengan gaya yang khas, memiliki pola pikir, sikap dan perilaku yang sesuai dengan budaya bangsa Indonesia dan berjiwa sesuai dengan pedoman nilai-nilai Pancasila.

\section{b. Pendidikan Kewarganegaraaan Pembangun Karakter Bangsa}

Menurut pendapat Rosyada, dkk (2000: 7), Pendidikan Kewarganegaraan sama dengan Pendidikan Demokrasi yang memiliki tujuan untuk mempersiapkan warga masyarakat untuk dapat berfikir kritis dan bertindak demokratis, melalui aktivitas menanamkan kesadaran demokrasi adalah bentuk kehidupan masyarakat yang paling menjamin hak-hak warga masyarakat.

Somantri memberikan ciri-ciri mengenai PKn yaitu: 1) PKn merupakan kegiatan seluruh program sekolah; 2) PKn meliputi berbagai macam kegiatan mengajar yang dapat menumbuhkan hidup dan perilaku yang lebih baik dalam masyarakat demokratis; dan, 3) dalam PKn termasuk pula hal-hal yang bersangkutan dengan pengalaman, kepentingan masyarakat, pribadi dan syarat- syarat objektif untuk hidup bernegara.

Sedangkan meurut Rosyada, dkk (2000: 10) tujuan dari PKn diantaranya sebagai berikut: (1) Untuk membentuk kecakapan partisipatif yang bermutu dan bertanggung jawab dalam kehidupan politik dan masyarakat, baik ditingkat lokal, nasional, regional dan global; (2) Menjadikan warga masyarakat yang baik dan mampu menjaga persatuan dan integrasi bangsa guna mewujudkan Indonesia yang kuat, sejahtera, dan demokratis; (3) Menghasilkan mahasiswa yang berfikiran komprehensif, analitis, kritis, dan bertindak demokratis; (4) Mengembangka kultur demokrasi, yaitu kebebasan, persamaan, kemerdekaan, toleransi, kemampuan mengambil keputsan serta kemampuan berpartisipasi dalam kegiatan politik kemasyarakatan; (5) Mampu membentuk mahasiswa menjadi good and responsible citizen (warga negara yang baik dan bertanggung jawab) melalui penanaman moral dan keterampilan (social skills) seingga kelak mereka mampu memahami dan memecahkan persoalan-persoalan actual kewarganegaraan seperti toleransi, perbedaan pendapat, bersikap toleransi, perbedaan pendapat, bersikap empati, menghargai pluralitas, keasadaran hukum dan tertib sosial, menjunjung tinggi HAM, mengembangkan demokratisasi dalam berbagai lapangan kehidupan, dan menghargai kearifan lokal (local wisdom). 
Pendidikan merupakan upaya yang strategis dalam pembentukan sistem nilai yang ada dalam diri seseorang, yang kaitannya dengan perwujudan hrkat dan martabat sebagai manusia sesuai dengan tatanan kehidupan masyarakt yang melingkupinya. Pendidikan senantiasa mmengarahkan upaya dalam peningkatan kesadaran dan martabat seseorang baik secara pribadi maupun sebagai anggota masyarakat suatu bangsa. Pendidikan adalah usaha sadar dan terencana untuk mewujudkan suasana belajar dan proses pembelajaran agar peserta didik secara aktif mengembangkan potensi dirinya untuk memiliki kekuatan spiritual keagamaan, pengendalian diri, kepribadian, kecerdasan, akhlak mulia, serta keterampilan yang diperlukan dirinya, masyarakay, bangsa dan negara (UU RI No. 20 Tahun 2003)

Sehubungan dengan hal tersebut, pendidikan yang mengarahkan pada tujuan pembentukan karakter salah satunya yaitu PKn. Pkn sudah menadi bagian dari instrument pendidikan nasional untuk mencerdaskan kehidupan bangsa Indonesia. PKn mempersiapkan para peserta didik untuk menjadi warga negara yang baik dan cakap, berakhlak mulia, cerdas, partisipatif, dan bertanggung jawab. PKn menciptakan generasi yang berkarakter dan memiliki rasa nasionalisme yang tinggi. nilai-nilai dalam pendidikan karakter adalaah suatu sisten penanaman nilai-nilai karakter kepada warga sekolah yang meliputi komponen pengetahuan, kesadaran, kemauan, dan pola tindakan untuk melaksanakan nilai-nilai tersebut. Nilai karakter hars ditanamkan sejak dini, hal ini karena akan membentuk pembiasaan diri dalam melaksanakan nilai-nilai karakter dalam kehidupan tanpa mereka sadari dan secara perlahan akan membentuk karakter baik dalam diri peserta didik sebagai generasi penerus bangsa yang rentan dengan terjangan arus globalisasi, yang akan membawa mereka secara perlahan akan meninggalkan jatidiri bangsa Indonesua dengan hidup apatis (Rahmatiani,2017).

Inti dari kepribadian warga negara adalah kebijakan kewarganegaraan (civic virtues). Pengembangan kebijakan kewarganegaraan perlu ditopang dengan adanya pengembangan elemen-elemen yang meliputinya yakni: wawasan atau pengetahuan kewarganegaraan (civic knowladge), sikap kewarganegaraan (civic disposition), keterampilan kewarganegaraan (civic commitment), kepercayaan diri kewarganegaraan (civic confidence). Secara umum, pengembangan kebijakan kewarganegaraan sangat siperlukan oleh setiap orang agar mampu mewujudkan partisipasi kewarganegaraan yang cerdas dan bertanggung jawab (intelligent and responsible civic participation). Berkaitan dengan hal itu, PKn berperan dan bertanggung jawab yang sangat penting dalam mempersiapkan warga negara agar memiliki komitmen yang kuat serta konsisten untuk mempertahakan NKRI. PKn memberikan kontribusi terhadap tanggung jawab pendidikan yang memiliki fkus pada pembentukan diri dari bidang agama, sosio-kulturak, suku bangsa, bahasa, untuk menjadikan warga negara yang cerdas, terampil, dan berkarakter yag dilandasi oleh Pancasila dan UUD 1945.

Dasim Budimansyah (dalam Sulistyarini, 2015: 6) menyatakan bahwa pendidikan kewarganegaraan diartikan sebagai kontribusi pendidikan terhadap perkembangan karakteristik yang menandai sebagai kontribusi pendidikan terhadap perkembangan karakteristik yang menandai sebagai warga negara. Ada tiga peran PKn msnurut Dasim Budimansyah, peertama, berdasarkan pendekatan psycopaedagogical development yakni PKn sebagai program kulikuler di lembaga pendidikan formal (sekolah/perguruan tinggi), maupun nonformal (luar sekolah), yang berperan sebagai instrument pemuliaan dan pemberdayaan anak dan pemuda sesuai potensinya agar menjadi warga negara yang baik dan cerdas (smart and good citizen). Kedua, berdasarkan pendekatan socio-cultural development yakni PKn sebagai gerakan sosio-kultural kewarganegaraan yang berperan sebagai aktualisasi diri warga negara, baik secara perorangan maupun kelompok sesuai dengan hak, kewajiban, dan konteks sosial budayanya, malalui partisipasi aktif secara cerdas dan bertanggung jawab. Ketiga, berdasarkan pendekatan socio- political intervention yakni PKn sebagai program pendidikan politik kebangsaan bagi para penyelenggara Negara, anggota dan pimpinan organisasi social dan organisasi politik yang dikemas dalam 
berbagai bentuk pembinaan pengetahuan kewarganegaraan (civic knowledge), kecakapan kewarganegaraan (civic skills), dan kebajikan kewarganegaraan (civic disposition).

Berdasarkan aspek yuridis, kurikulum pendidikan dasar, menengah dan perguruan tinggi diwajibkan memuat PKn dengan tujuan untuk membentuk peserta didik menjadi manusia yang memiliki rasa kebangsaan dan cinta tanah air sesuai dengan Pancasila dan UUD 1945. PKn dapat memberikan kontribusi pembangunan karakter bangsa, dapat dilihat dari tiga aspek yaitu menurut pendapat dari Winataputra (2001), pertama, curriculum content atau konten kurikulum, berdasarkan surat keputusan Dirjen Dikti No. 43/Dikti 2006 obyek pembahasan dalam PKn diantaranya: Filsafat Pancasila, Identitas Nasional, Negara dan Konstitusi, Demokrasi Indonesia, HAM dan Rule of Law, Hak dan Kewajiban Warga Negara, Geopolitik Indonesia, dan Geostrategi Indonesia. Pokok PKn tersebut menjadi dasar dalam pembangunan karakter warga negara yang selanjutnya akan terkumpul menjadi karakter bangsa. Dalam tuntutan dan perkembangan zaman, para guru/dosen memiliki tanggung jawab untuk mengembangkan materi-materi tersebut.

Kedua, mata pelajaran PKn dalam pembeljarannya seharusnyaa dilihat dan diperlakukan sebagai praktek demokrasi. Pendekatan yang disarankan dalam pembelajaran adalah pembelajaran yang lebih berorientasi pada proses bepikir kritis dan pemecahan masalah. Ketiga, pada saat bersamaan lingkungan masyarakat sekolah dan masyarakat luas seharusnya dikondisikan untuk menjadi tempat pembelajaran "spiral global classroom" (Cogan, 1999:7). Dalam hal ini, pendidikan dalam rangka pembentukan karakter, tidak hanya berasal dari lembaga pendidikan seperti sekolah atau perguruan tinggi saja, melainkan diperlukan kesadaran bahwa pembangunan karakter merupakan tugas dari semua pihak, baik orang tua, anggota keluarga, dan juga masyarakat sekitar. Karenanya, kerja sama antara lembaga pendidikan, orang tua dan juga lingkungan masyarakat sangat dibutuhkan.

Sejalan dengan yang disampaikan Purwito (1996) bahwa berhasil tidaknya proses pendidikan menjadi tanggung jawab bersama antara orang tua, pemerintah/ lembaga pendidikan dan masyarakat. Pembentukan karakter merupakan tanggung jawab bersama baik dari lembaga pendidikan, orang tua dan juga lingkungan sekitar. Karena apabila salah satu dari pendukung dalam pembentukan karakter tersebut tidak saling bekerja sama maka, tujaun untuk membentuk generasi muda yang memiliki karakter yang baik bagi bangsa tentunya tidak akan pernah berhasil dalam mencapai tujuan tersebut.

\section{KESIMPULAN}

Pada dasarnya karakter yang sesuai dengan karakter bangsa Indonesia merupakan karakter warga negara yang berlandaskan dengan Pancasila dan Undang-Undang Dasar 1945. Karakter manusia yang berketuhanan, yang adil dalam beradab, tidak memecah belah persatuan bangsa Indonesia, bermusyawarah, dan berkeadilan sosial. Dalam Pancasila sudah terangkum karakter yang sesuai dengan bangsa Indonesia. Namun, seiring dengan perkembangan zaman karakter bangsa Indonesia yang beretika dan bermoral seakan perlahanlahan luntur. Untuk itu, Pendidikan Kewarganegaraan yang merupakan salah satu instrument pambentuk karakter bangsa sangat diperlukan dalam kurikulum pembelajaran. Pendidikan karakter harus dikembangkan sejak dini kepada peserta didik, sejalan dengan kewajiban bagi peserta didik untuk melaksanakan pembelajaran dari tingkat sekolah dasar, menengah, tingkat atas bahkan sampai dengan tingkat Perguruan tinggi.

Pembelajaran yang sesuai dalam pembentukan karakter bangsa yaitu pembelajaran yang dapat dilaksanakan dengan peserta didik yang ikut berpartisipasi aktif, sehingga peserta didik dapat memahami dan menerapkan dalam kehidupan sehari-hari sebagai karakter yaag dimilikinya. PKn merupakan pembelajaran yang mendasari bagi warga negaranya untuk memiliki karakter bangsa yang baik dan berbudi luhur. Namun begitu, untuk dapat membentuk karakter bangsa yang baik tersebut bukan hanya tanggung jawab lembaga pendidikan semata, tetapi orang tua, keluarga dan lingkungan sekitar pun memiliki peran penting dalam pembangunan karakter. Untuk itu, lembaga pendidikan, orang tua dan juga lingkungan sekitar 
harus bekerja sama dalam pembentukan karakter bangsa. Jika salah satunya tidak dapat mendukung pembentukan karakter, maka jangan menyalahkan kepada salah satu pihak saja apabila pembentukan karakter yang dibangun justru tidak membuahkan hasil yang maksimal, karena pembentukan karakter bangsa tidak hanya tanggung jawab salah satu pihak saja.

\section{DAFTAR PUSTAKA}

Akbal, M. (2016). Pendidikan Kewarganegaraan dalam Pembangunan Karakter Bangsa. Seminar Nasional, (2) 485-493. Diakses dari https://ojs.unm.ac.id/PSNHSIS/article/view/4084. Berakar Pada Karakter; Isuisu Permasalahan Bangsa, Lembaga Penerbitan Fakultas Ekonomi Universitas Indonesia.

Cogan, J.J. (1999). Developing the Civic Society: The Role of Civic Education, Bandung: CICED

Departemen Pendidikan Nasional. (2003). Undang-undang Republik Indonesia No. 20 Tahun 2003 tentang Sistem Pendidikan Nasional.

Dianti, P. (2014). Integrasi Pendidikan Karakter dalam Pembelajaran Pendidikan Kewarganegaraan untuk Mengembangkan Karakter Siswa.

Herlina, N. (2017). Pendidikan Kewarganegaraan dan pancasila untuk Membangun Karakter Bnagsa Indonesia di Universitas PGRI Palembang Provinsi Sumatera Selatan (Prospek dan Tantangan bagi Mahasiswa Universitas PGRI Palembang). Prosiding Seminar Nasional, 124-129. Diakses dari https://jurnal.univpgri- palembang.ac.id/index.php/Prosidingpps/article/view/1352

Izma, T., \& Kesuma, V., Y. (2019). Peran Pendidikan Kewarganegaraan dalam Membangun Karakter Bangsa. Jurnal Ilmu Kependidikan Wahana Didaktika, 17(1) 8492. DOI: http://dx.doi.org/10.31851/wahanadidaktika.v17i1.2419

Juliardi, B. (2015). Implementasi Pendidikan Karakter Melalui Pendidikan Kewarganegaraan. Jurnal Bhinneka Tunggak Ika, 2(2) 119-126. Diakses dari https://ejournal.unsri.ac.id/index.php/jbti/article/view/4581.

Muhadjir, N. (2000). Metodologi penelitian kualitatif: Pendekatan positivistik, rasionalistik, phenomenologik, dan realisme metaphisik telaah studi teks dan penelitian agama (IV). Rake Sarasin.

Purbaya, A. A. (2018). "Video Guru di Bully Murid di Kendal Viral, Kepsek: Hanya Bercanda". Diakses dari https://news.detik.com/berita-jawa-tengah/d-4297429/videoguru-di-bully- murid-di-kendal-viral-kepsek-hanya-bercanda

Purwito, Edy, Drs. 1996. Sosiologi. Surakarta: Widya Duta

Rahmatiani, L. (2020). Pendidikan Kewarganegaraan Sebagai Pembentuk Karakter Bangsa. Seminar Nasional Kewarganegaraan. 87-94. Diakses dari http://seminar.uad.ac.id/index.php/snk/article/view/3665.

Rosyada, Dede. et.al. (2003). Pendidikan Kewarganegaraan: Civic Education Demokrasi, Hak Asasi Manusia Masyarakat Madani. Jakarta: Prenada Media.

Rozak, A., Sayuti, W., \& Salim GP, M. A. (2005). Rosyada, D., Ubaidillah, A., Pendidikan Kewargaan (Civic Education): Demokrasi, Hak Asasi Manusia, dan Masyarakat Madani. Kerjasama ICCE UIN Syarif Hidayatullah dengan Prenada Media

Sulistyarini. (2015). Pengembangan Karakter Berbasis Pancasila Melalui Pendidikan Kewarganegaraaan. Jurnal Bhinneka Tunggal Ika, 2(1) 1-7 . DOI: https://doi.org/10.36706/jbti.v2i1.4554

Wahyu. (2011). Masalah dan Usaha Membangun Karakter Bangsa. Jurnal Komunitas, 3(2) 134- 149. DOI: https://doi.org/10.15294/komunitas.v3i2.2310

Winataputra, U.S. (2001). Jatidiri Pendidikan Kewarganegaraan sebagai Wahana Sistemik Pendidikan Demokrasi: Suatu Kajian Konseptual dalam Konteks Pendidikan IPS. Disertasi pada PPS UPI, tidak diterbitkan. 